Article

\title{
Turbine Characteristics of Wave Energy Conversion Device for Extraction Power Using Breaking Waves
}

\author{
Paresh Halder*D, Hideki Takebe, Krisna Pawitan, Jun Fujita, Shuji Misumi and \\ Tsumoru Shintake $\mathbb{D}$
}

Okinawa Institute of Science and Technology Graduate University, 1919-1 Tancha, Onna-son, Okinawa 904-0495, Japan; hideki.takebe@oist.jp (H.T.); krisna.pawitan@oist.jp (K.P.); jun.fujita@oist.jp (J.F.);

SHUJI.MISUMI@OIST.JP (S.M.); shintake@oist.jp (T.S.)

* Correspondence: paresh.halder@oist.jp

Received: 12 November 2019; Accepted: 7 February 2020; Published: 21 February 2020

check for updates

\begin{abstract}
A new type of wave energy converter which harnesses electricity from onshore breaking waves has been studied at Okinawa Institute of Science and Technology Graduate University (OIST) since 2014. This concept has been demonstrated at a coral beach on the Maldives since 2018. Wave energy conversion is possible when waves approaching the shore steepen due to decreased water depth resulting in wave breaks near the surface. A steepened wave reaches the critical velocity of $4 \sim 6 \mathrm{~m} / \mathrm{sec}$ shoreward before it breaks. A rotating blade takes advantage of this breaking phenomenon to convert the wave energy into electricity. The work presented here includes an experimental and numerical investigation of a prototype model of the wave energy converter. The turbine having five blades of variable chord lengths, twist angles, and constant thickness profile from hub to tip was simulated under similar flow as well as testing conditions, to predict the turbine performance. A commercial computational fluid dynamic tool SolidWorks Flow Simulation 2018 was used for the simulations at various rotation speeds with a uniform inlet velocity. The modified $k-\varepsilon$ with a two-scale wall function turbulence closure model was selected. The validation performed for different test cases showed that the present computational results match in good agreement with the experimental results. Additionally, details performance of the turbine running, and generator characteristics have been reported in this paper.
\end{abstract}

Keywords: wave energy conversion device; breaking wave; computational fluid dynamics; turbine and generator characteristics

\section{Introduction}

The ocean waves hold a vast amount of energy and represent viable solution to solve our ever-growing energy demand. Although its easy availability, immature energy extraction technology restricts the commercialization of wave energy converters (WEC) [1]. Several authors have been proposed various types of design and investigated for wave energy conversion devices [2-4]. One of the most observed wave energy converters types is Oscillating Water Column (OWC) type WEC [2,5]. This device utilized a water column trapped inside a chamber with the bottom still connected into the ocean. As the wave passes, the water column moves up and down, forcing the air out and into the chamber via a power take-off mechanism. This power take-off mechanism consists of a unique bi-directional turbine that will rotate in the same direction even if the airflow comes from the top or the bottom section of the turbine. Over the years, many iterations of this state-of-the-art turbine have been made. This became a valuable lesson in turbine design and optimization processes.

Table 1 provides the list of design modifications of most popular bi-directional turbines, Wells and impulse turbines, used in an OWC type WEC and their outcome on performance. Earlier literature 
revealed that various efforts have been made and methods have been proposed to increase the performance of Wells and impulse turbines. Similar investigations have revealed that modifications of design parameters such as blade sweep, shape, variable pitch angle, blade solidity, end-wall, guide vane, bi-plane, the skew blade can certainly improve the performance of the turbine.

Table 1. Some prominent studies of Wells and Impulse turbines for wave energy conversion.

\begin{tabular}{|c|c|c|c|}
\hline \multicolumn{4}{|c|}{ Wells Turbine } \\
\hline Design Modification & Advantage & Description & Profile \\
\hline $\begin{array}{l}\text { Sweep with and without } \\
\text { guide vane [6] }\end{array}$ & Higher operating range & $\begin{array}{l}\text { Bypass pressure-relief valve produced } \\
\text { higher electrical energy. }\end{array}$ & NACA0015 \\
\hline Aerofoil shape [7] & $\begin{array}{l}\text { Increased power output (average } \\
\text { relative gain: }+11.3 \% \text { Improved } \\
\text { efficiency: } 1 \%\end{array}$ & Incident angle varied: 5 to $14^{\circ}$ & NACA0021 \\
\hline Blade sweep [8] & Overall efficiency improved & $30^{\circ}$ backward sweep & NACA0015 \\
\hline Blade sweep [9] & Improved overall performance & Blade sweep range: $0.25-0.75$ & NACA0020 \\
\hline Pitch angle [10] & $\begin{array}{c}\text { Improved efficiency: } 2.3 \% \text { and AOP } \\
\text { efficiency: } 6.2 \% .\end{array}$ & Optimum pitch angle: $0.3^{\circ}$ & NACA0021 \\
\hline Pitch angle [11] & $\begin{array}{c}\text { Average increase in efficiency: } 3.4 \%, \\
\text { power: } 1 \% .\end{array}$ & Optimum pitch angle: $0.6^{\circ}$ & NACA0021 \\
\hline Endplate [12] & Improved efficiency by $4 \%$ & $\begin{array}{l}\text { Endplate thickness: } 0.5 \mathrm{~mm} \text { and plate } \\
\text { margin: } 0 \text { to } 0.3 \mathrm{~mm}\end{array}$ & NACA0020 \\
\hline $\begin{array}{l}\text { Blade profile Thickness } \\
\text { [13] }\end{array}$ & $\begin{array}{c}\text { The NACA0021 produced peak } \\
\text { efficiency. Efficiency drop: } 10 \% \text { with } \\
\text { blade roughened blade. }\end{array}$ & $\begin{array}{l}\text { Thicker and modified aerofoil blades } \\
\text { improved the performance of the } \\
\text { turbine. }\end{array}$ & $\begin{array}{l}\text { NACA0024, NACA0021, } \\
\text { NACA0015H, } \\
\text { NACA0015, NACA0012 }\end{array}$ \\
\hline $\begin{array}{l}\text { Blade sweep and pitch } \\
\text { angle [14] }\end{array}$ & Improved turbine performance & $\begin{array}{c}30^{\circ} \text { backward sweep and blade pitch } \\
\text { angle: } 0 \text { to } 20^{\circ}\end{array}$ & NACA0015 \\
\hline Blade profile [15] & $\begin{array}{l}\text { Efficiency improved at an angle of } \\
\text { attack }<7^{\circ} \text {. Stall angle }=10^{\circ} .\end{array}$ & $\begin{array}{l}\text { Fan-shaped blades with different } \\
\text { sweep angles }\end{array}$ & NACA0021, NACA0012 \\
\hline Blade profile [16] & Higher peak efficiency & Optimum blade profile: NACA0015 & $\begin{array}{c}\text { NACA0015, NACA0020, } \\
\text { CA9, HSIM } \\
15-262133-1576\end{array}$ \\
\hline Blade geometry [17] & $\begin{array}{l}\text { The stall margin is higher with a } \\
\text { higher hub-tip ratio. }\end{array}$ & $\begin{array}{l}\text { Optimum blade sweeps ratio of } 0.35 \\
\text { and solidity of } \sim 0.67 \text {. }\end{array}$ & NACA0020 \\
\hline Blade profile [18] & Higher power output & Preferable rotor blade profile CA9 & $\begin{array}{c}\text { NACA0015, NACA0020, } \\
\text { CA9, HSIM } \\
15-262133-1576\end{array}$ \\
\hline Casing groove [19] & $\begin{array}{l}\text { Higher power output and operating } \\
\text { range }\end{array}$ & $\begin{array}{l}\text { Introduced circumferential casing } \\
\text { groove }\end{array}$ & NACA0015 \\
\hline $\begin{array}{l}\text { Blade sweep and } \\
\text { thickness [20] }\end{array}$ & $\begin{array}{l}\text { Stall margin and power enhanced by } \\
22.2 \% \text { and } 33 \% \text {, respectively. }\end{array}$ & $\begin{array}{l}\text { Optimize the blade sweep and } \\
\text { thickness }\end{array}$ & NACA0015 \\
\hline Blade sweep [21] & $\begin{array}{l}\text { Stall margin and power enhanced by } \\
18 \% \text { and } 29 \% \text {, respectively. }\end{array}$ & Optimize the blade sweep angle & NACA0015 \\
\hline $\begin{array}{l}\text { Sweep, thickness and } \\
\text { casing groove [22] }\end{array}$ & $\begin{array}{l}8 \% \text { increment efficiency and } 17.4 \% \\
\text { decrement in torque. }\end{array}$ & $\begin{array}{l}\text { Optimize the Blade sweep and } \\
\text { thickness along with the casing } \\
\text { groove }\end{array}$ & NACA0015 \\
\hline $\begin{array}{l}\text { Static extended trailing } \\
\text { edge [23] }\end{array}$ & $\begin{array}{l}\text { Improved relative mean torque by } \\
23.4 \% \text { and, reduced relative mean } \\
\text { efficiency by } 5.4 \% \text {, before stall } \\
\text { condition }\end{array}$ & $\begin{array}{l}\text { Static extended trailing edge with } 5 \% \\
\text { chord length }\end{array}$ & NACA0015 \\
\hline $\begin{array}{l}\text { Radiused edge blade tip, } \\
\text { static extended trailing } \\
\text { edge, and thickness [24] }\end{array}$ & $\begin{array}{c}22 \% \text { and } 97 \% \text { relative stall margin and } \\
\text { the turbine power. }\end{array}$ & $\begin{array}{l}\text { Fixed SETE at LE and extending TE } \\
\text { without altering the original features } \\
\text { of the airfoil. Length, thickness, and } \\
\text { deflection are fixed as } 5 \% \text { C, } 0.25 \mathrm{~mm} \\
\text { and } 0^{\circ} \text {, respectively }\end{array}$ & NACA0015 \\
\hline \multicolumn{4}{|c|}{ Impulse Turbine } \\
\hline Blade thickness [25] & Improved efficiency. & Camber line iterative design & Circular - elliptical \\
\hline $\begin{array}{l}\text { Number of blades and } \\
\text { GVs [26] }\end{array}$ & Enhance efficiency $13 \%$ & Surrogate-based optimization & Circular - elliptical \\
\hline $\begin{array}{l}\text { Hub and tip thickness } \\
\text { [27] }\end{array}$ & $10.4 \%$ efficiency improvement & Surrogate-based optimization & Circular - elliptical \\
\hline $\begin{array}{l}\text { Number of blades and } \\
\text { GVs along with GV } \\
\text { angle and profile. [28] }\end{array}$ & $\begin{array}{l}24 \% \text { efficiency enhancement for the } \\
\text { entire flow range }\end{array}$ & Surrogate-based optimization & Circular - elliptical \\
\hline
\end{tabular}


All of the improvements were good news for the device efficiency. However, none of the authors reported how much energy can be extracted from the ocean breaking wave. Imagining that the density of water is 1000 times higher than air, we may obtain better power output if we extracted energy directly from the seawater. This idea led to the first novel concept and design procedure of harnessing energy from the ocean breaking wave, which explained in [29]. He investigated the water velocity at the seashore breaking wave zone and performed the first experimental tests of such a wave energy converter (WEC) in June 2015. This experiment continued to a real sea deployment testing which reported in [30-33]. It is observed that the maximum peak power obtained was about $400 \mathrm{~W}$ for an incoming wave velocity of $3.1 \mathrm{~m} / \mathrm{s}$.

In this paper, firstly a previously done experiment to validate the numerical data is presented in Section 2 (Experimental setup) and Section 3 (Experimental results). Next, the Reynolds-averaged Navier-Stokes Equations (RANS) solver was used for in the numerical simulation. The Advanced Boundary Cartesian Meshing technique was deployed for the entire geometry. A detailed geometry, solution procedure, analysis of the results, and characteristics of the turbine are discussed in Section 4 (Numerical methodology). The results of the numerical analysis will be compared with the experimental results and discussed in Section 5. Electricity generation characteristics will be presented in Section 6 . Finally, the conclusions will be drawn in Section 7.

\section{Experimental Setup}

Figure 1 summarized a more detail schematic layout of the turbine testing using the water tunnel at West Japan Fluid Engineering Laboratory Co., Ltd as reported in [33]. The water tunnel is $1.5 \mathrm{~m}$ long, $1.25 \mathrm{~m}$ width and $6 \mathrm{~m}$ height. It consists of an open boat with a rotor blade, calibrated pitot tube, motor controller and a data logger including dynamic strain gauges, torque meter. The open boat is placed $0.46 \mathrm{~m}$ below the water surface. A torque transducer and a load cell are attached to a rotor shaft which connected to a motor and data logger. These sensors measure the torque, flow speed, and control blade rotational speed, respectively. A calibrated pitot tube is connected to the differential pressure transducer, which is set $1.0 \mathrm{~m}$ upwind of the rotor and $0.4 \mathrm{~mm}$ below the water surface, to calculate the velocity profile.

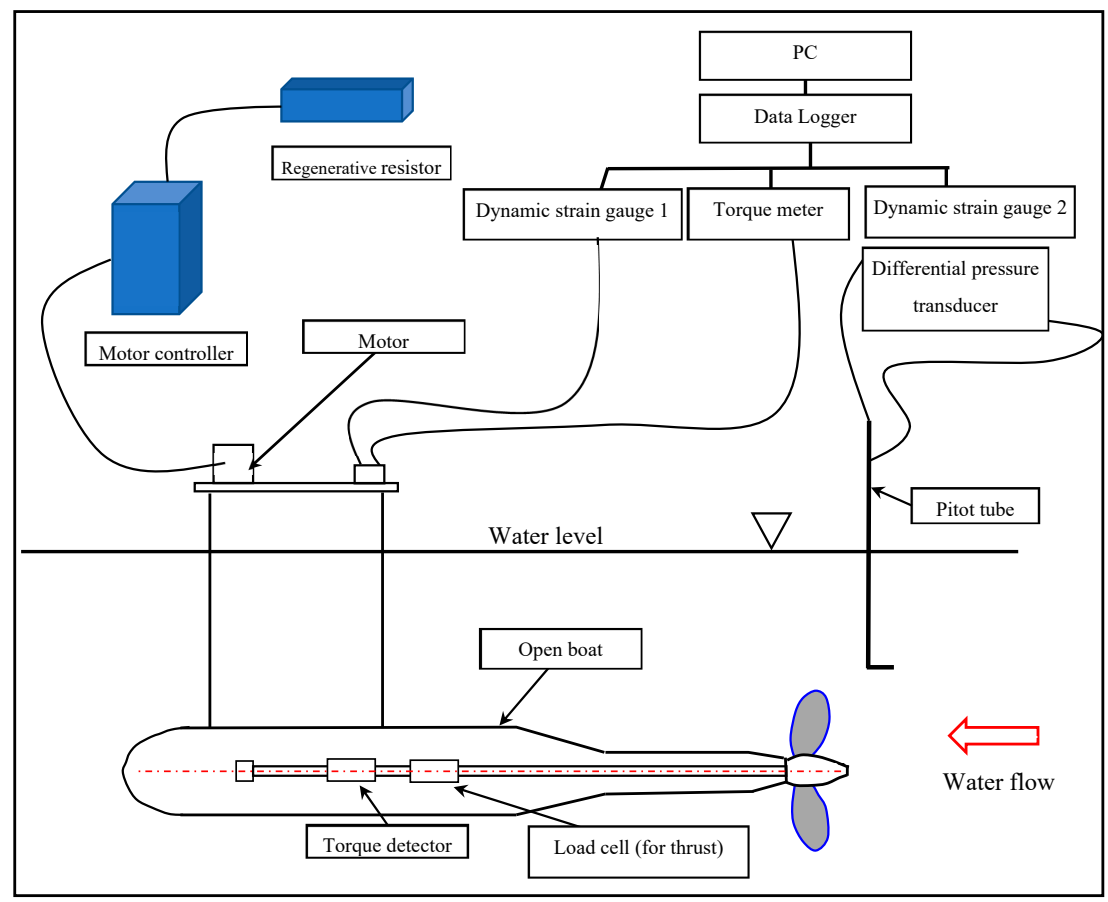

Figure 1. Schematic diagram of $0.35 \mathrm{~m}$ diameter test section at West Japan Fluid Engineering Laboratory Co., Ltd. 


\section{Experimental Results}

The performance of the turbine is calculated by the rotational speed $(\omega)$, inlet velocity $(V)$, the torque generated by the blade $(T)$, and blade swept area $(S)$. The results are articulated in the form of the power coefficient, $C p$, and tip speed ratio (TSR). The non-dimensional performance parameters are given below:

$$
\begin{aligned}
& \text { Power Coefficient, } c_{p}=\frac{T \omega}{\frac{1}{2} \rho V_{0}^{3} S} \\
& \text { Tip Speed Ratio }(T S R)=\frac{\omega R}{V_{0}}
\end{aligned}
$$

The experimental test was carried out under steady conditions at a constant inlet velocity in the range of 1.0-3.0 m/s as mentioned in [33]. A wider range of inlet velocity effect on the turbine performance is shown in Figure 2 against a wider TSR. It is noticed that, as the inlet velocity increases, the peak $C p$ also increases, and the maximum power is obtained for $T S R=2.5$ at velocity $1.50 \mathrm{~m} / \mathrm{s}$. Further increasing velocity, the peak power also increases. At velocity $2.50 \mathrm{~m} / \mathrm{s}$, the maximum power is almost the same as the velocity $1.50 \mathrm{~m} / \mathrm{s}$. Further increasing velocity, the peak power decreases which caused the adverse pressure gradient. In the present work, the optimum inlet velocity of $2.50 \mathrm{~m} / \mathrm{s}$ is considered for the numerical study.

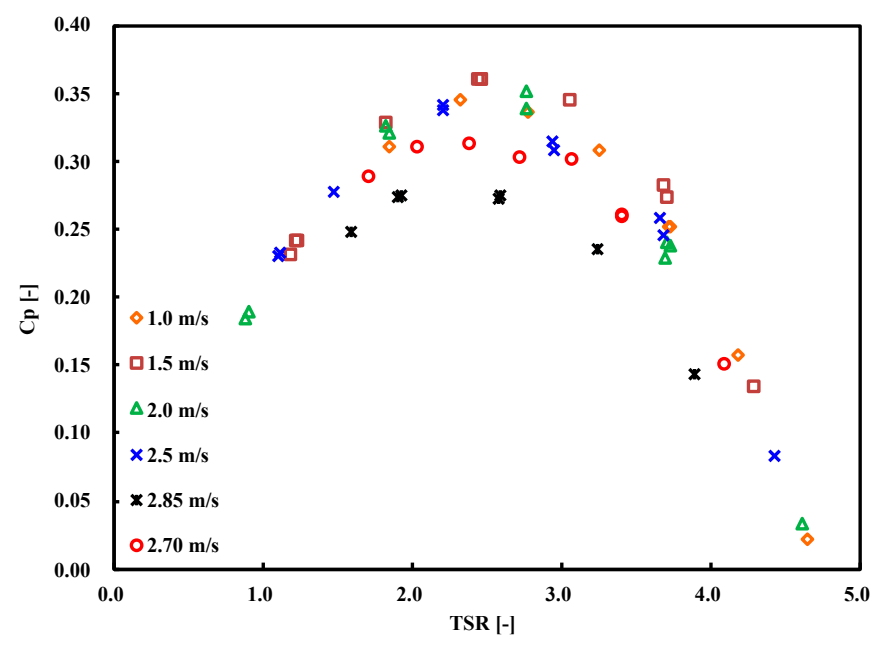

Figure 2. $C p$ vs. TSR of the half scale turbine at different inlet velocity; Experimental results [33].

\section{Numerical Methodology}

The reference full-scale wave breaking turbine design and geometry were adopted based on the optimum design parameter [29]. The blade has a tip diameter $\left(D_{t}\right)$ of $0.7 \mathrm{~m}$, hub to tip ratio $\left(D_{h} / D_{t}\right)$ of 0.214 , a chord length $(C)$, at hub and tip section based on TSR 2 and 4, respectively and a blade twist angle $(\theta)$, varies from hub to tip with constant tip speed ratio $(T S R=2)$ as shown in Figures 3 and 4 . The twist angle and chord length, $C$, are defined as:

$$
\begin{gathered}
\text { Twist angle, } \theta=\frac{2 R}{3 \lambda r} \\
\text { Chord length, } \mathrm{C}=\frac{\eta}{C_{l}} \frac{2 \pi r / Z}{\left[\frac{4}{9}+\left(\frac{\lambda r}{R}\right)^{2}\right]}
\end{gathered}
$$




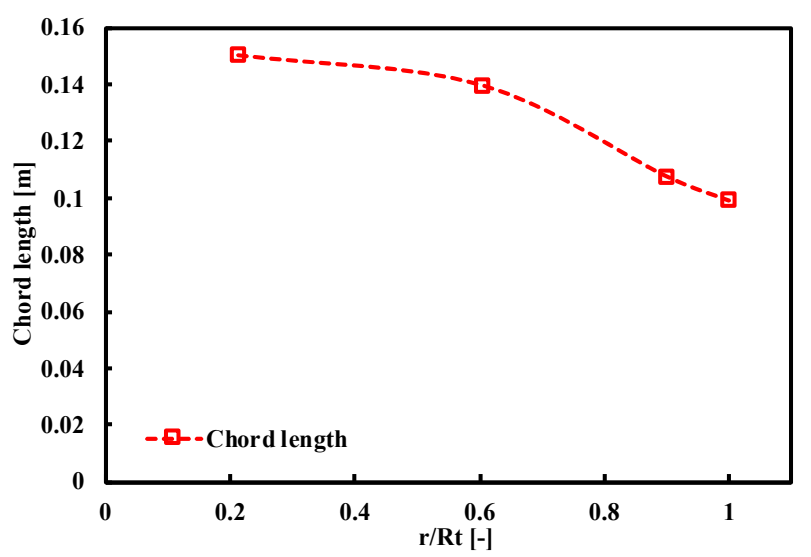

Figure 3. Chord length distribution along the blade span.

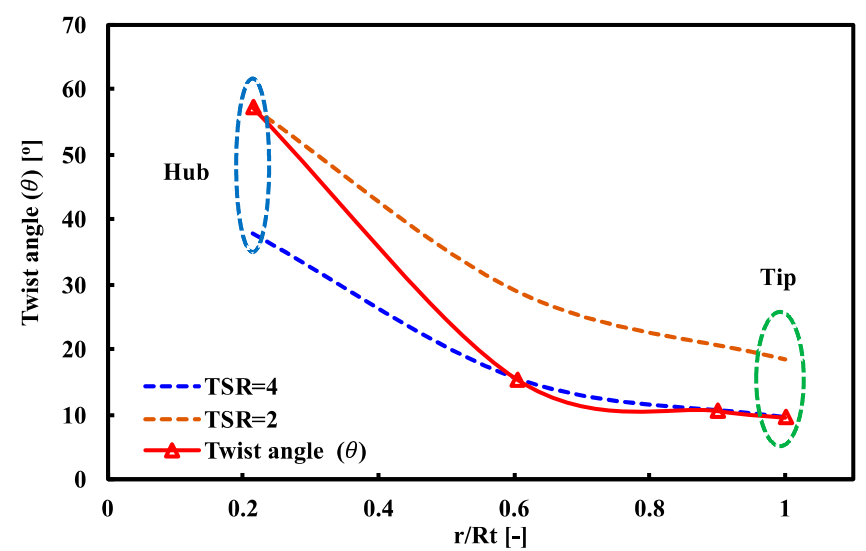

Figure 4. Twist angle distribution along the blade span.

Assume small angle of attack $C_{l}=0.3$ and $\eta=0.3$.

The turbine consists of five blades with constant blade thickness, $t$. The 2-D blade and 3-D Computer-Aided Design (CAD) model of the turbine are shown in Figure 5a,b, respectively.

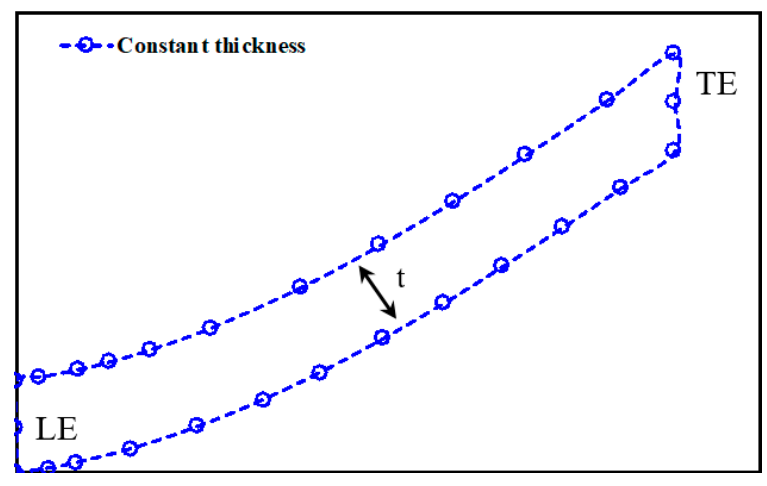

(a)

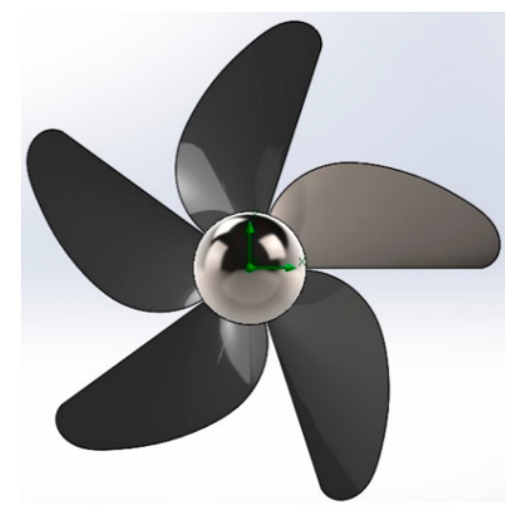

(b)

Figure 5. Definition of the blade: (a) Definition of 2-D blade profile; (b) 3-D CAD model.

The computational work was carried out by solving 3-D incompressible, steady Reynolds-averaged Navier-Stokes (RANS) equations, which were discretized based on finite volume approach. A Finite Volume Method (FVM) based commercial Computational Fluid Dynamics (CFD) solver SolidWorks Flow Simulation (SWFs), which includes the semi-implicit method for pressure linked equations 
(SIMPLE) algorithm was adopted. The modified $\kappa-\varepsilon$ with two-scale wall function was used as the turbulence closure model with equations are as follows [34].

(i) Modified $k-\varepsilon$ Turbulence Model:

$$
\begin{gathered}
\frac{\partial \rho k}{\partial t}+\frac{\partial \rho k u_{i}}{\partial x_{i}}=\frac{\partial}{\partial x_{i}}\left(\left(\mu+\frac{\mu_{i}}{\sigma_{k}}\right) \frac{\partial k}{\partial x_{i}}\right)+\tau_{i j}^{R} \frac{\partial u_{i}}{\partial x_{j}}-\rho \varepsilon+\mu_{i} P_{B} \\
\frac{\partial \rho \varepsilon}{\partial t}+\frac{\partial \rho \varepsilon u_{i}}{\partial x_{i}}=\frac{\partial}{\partial x_{i}}\left(\left(\mu+\frac{\mu_{i}}{\sigma_{\varepsilon}}\right) \frac{\partial \varepsilon}{\partial x_{i}}\right)+C_{\varepsilon 1} \frac{\varepsilon}{k}\left(f_{1} \tau_{i j}^{R} \frac{\partial u_{i}}{\partial x_{j}}+C_{B} \mu_{t} P_{B}\right)-f_{2} C_{s 2} \frac{\sigma \varepsilon^{2}}{k} \\
\tau_{i j}=\mu s_{i j}, \tau_{i j}^{R}=\mu_{t} s_{i j}-\frac{2}{3} \sigma k \delta_{i j}, s_{i j}=\frac{\partial u_{i}}{\partial x_{j}}+\frac{\partial u_{j}}{\partial x_{i}}-\frac{2}{3} \delta_{i j} \frac{\partial u_{k}}{\partial x_{k}}, P_{B}=-\frac{g_{i}}{\sigma_{B}} \frac{1}{\sigma} \frac{\partial p}{\partial x_{i}}
\end{gathered}
$$

where

$$
\begin{gathered}
C_{\mu}=0.09, C_{\varepsilon 1}=1.44, C_{\varepsilon 2}=1.92 ; \sigma_{k}=1, \sigma_{\varepsilon}=1.3, \sigma_{B}=0.9, C_{B}=1 \text { if } P_{B}>0, C_{B}=0 \\
\text { if } P_{B}<0
\end{gathered}
$$

The turbulent viscosity is defined as:

$$
\mu_{t}=f_{n} \cdot \frac{C_{p} \rho k^{2}}{\varepsilon}
$$

Damping function $f_{\mu}$ is obtained from Lam and Bremhorst's functions:

$$
f_{\mu}=\left(1-e^{-0.025 R_{y}}\right)^{2} \cdot\left(1+\frac{20.5}{R_{t}}\right)
$$

where

$$
R_{y}=\frac{\rho \sqrt{k y}}{\mu} ; R_{t}=\frac{\rho k^{2}}{\mu \varepsilon}
$$

and $y$ is the distance from a point to the Wall and Lam.

$f_{1}$ and $f_{2}$ are Bremhorst's damping function which evaluated from:

$$
f_{1}=\left(1+\frac{0.05}{f_{\mu}}\right) ; f_{2}=1-e^{R_{t}^{2}}
$$

Damping function $f, f_{1}$, and $f_{2}$ which decrease turbulent viscosity and turbulent energy and increase the turbulent dissipation rate when the Reynolds number $R_{y}$ based on the average velocity of fluctuations and distance from wall becomes too small, when $f_{\mu}=1, f_{1}=1$ and $f_{2}=1$ the approach obtains the original $k-\varepsilon$ model.

(ii) Two scale wall function

The two-scale wall functions incorporate the modified $k-\varepsilon$ turbulence model. The SWFS is used for computational mesh in immersed boundary non-body fitted cartesian meshing technique, which is required near the wall distance very small, $y+[34]$ :

$$
y^{+}=\frac{\sqrt{\rho \tau_{w} y}}{\mu}
$$

The solutions were converged when the maximum goal values were in the order of 5 for the selected output parameters. The inlet turbulence intensity was kept at $2 \%$, and the solution was iterated until the maximum goal was achieved. 
The blade geometry closer to the physical model has been considered, see Figure 6. No-slip boundary condition was applied at the hub and rotor blade, and a local averaging rotating domain with variable angular velocity was applied. A constant velocity profile was adopted at the inlet. Table 2 represents the details of boundary conditions used in the present analysis.

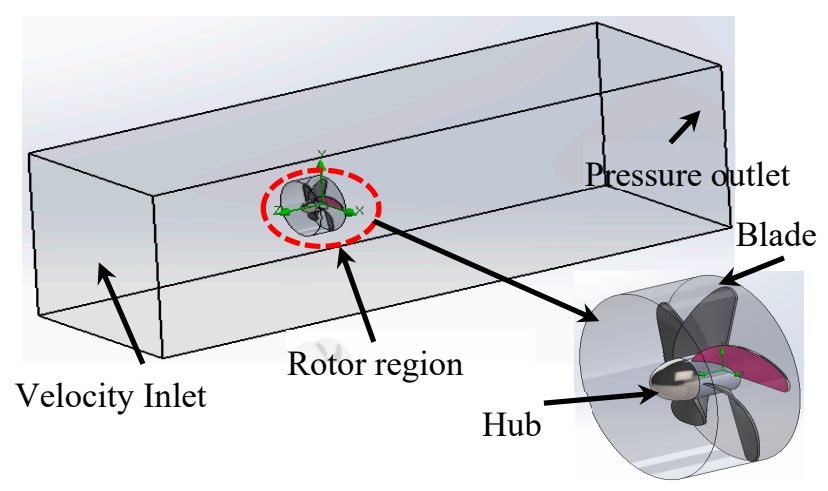

Figure 6. Computational domain with boundary conditions.

Table 2. Meshing and boundary conditions.

\begin{tabular}{cc}
\hline Parameter & Description \\
\hline CAD Model & SolidWorks \\
CFD Package & Full blade \\
Flow domain & SolidWorks Flow Simulation (SWFs) \\
Mesh/Nature & Immersed Boundary Cartesian Meshing Techniques \\
Reference frame & Local averaging frame \\
Working fluid & Water (assume temperature $\left.20^{\circ} \mathrm{C}\right)$ \\
Turbulence Model & Modified $\mathcal{\kappa}-\varepsilon$ with two-scale wall function \\
Inlet & Uniform velocity \\
Hub, rotor blade & No-slip wall \\
Outlet & Pressure outlet \\
Goal convergence & 5 \\
\hline
\end{tabular}

Figure 7 displays the mesh, which generated in SolidWorks Flow Simulation (SWFs), used in the computational domain. The Advanced Boundary Cartesian Meshing Technique was applied over the entire computational domain. The dense mesh was applied near the rotating region to capture the flow behavior near the blade region. The number of mesh was gradually increased in five steps from 210,901 to 1,044,949 nodes to check the grid-convergence, as shown in Figure 8. Here, a maximum deviation of $1.1 \%$ in the coefficient of power is obtained. Figure 8 also shows that the optimum number of mesh is about 0.63 million nodes.

Finally, eight partitions in the Dell Precision, with cluster specifications of Intel@Xeon $₫ C P U$ E3-1505M v6@ $3.00 \mathrm{GHz}$ processor was used to carry out the simulation. 


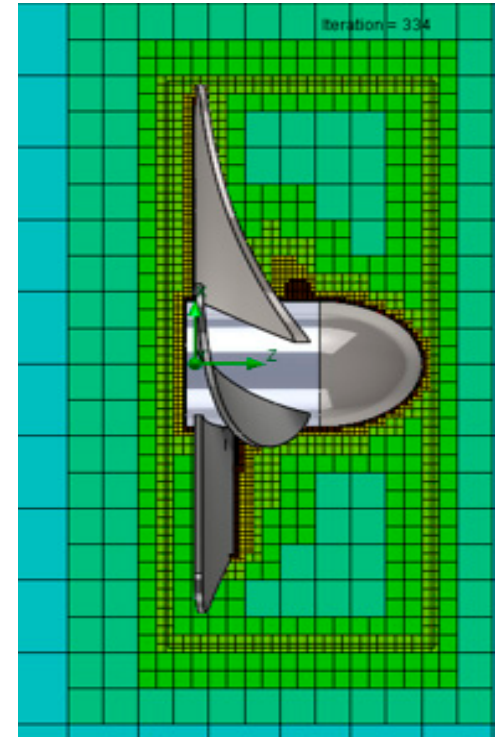

(a)

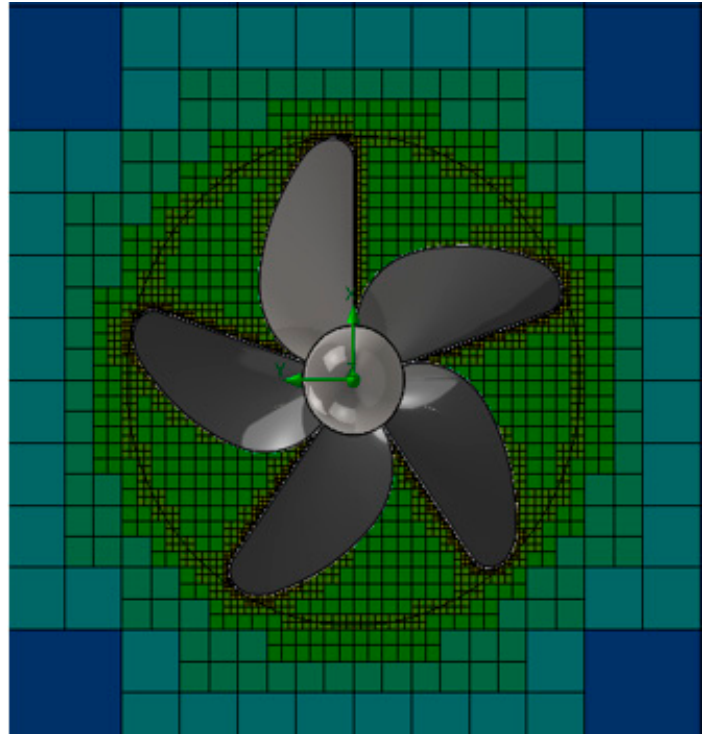

(b)

Figure 7. Computational Mesh around the rotor blade: (a) Side view; (b) Front view.

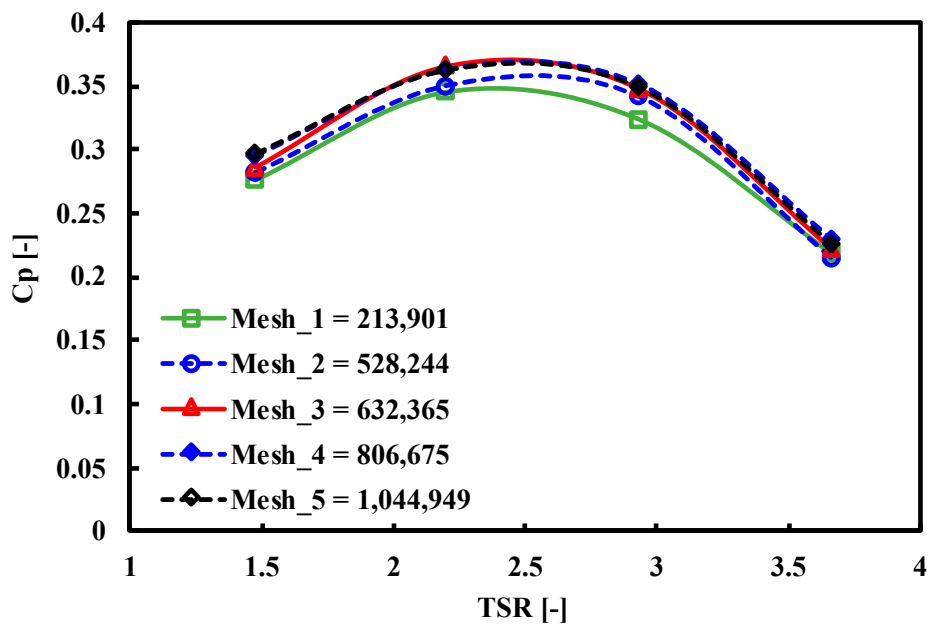

Figure 8. Grid sensitivity study (Power coefficient with mesh size at various TSR).

\section{Results and Discussion}

\section{Numerical Validation}

Present computational results are then compared with the experimental results shown in Figure 9. The turbine performance is obtained by plotting the coefficient of power against the TSR. It can be observed that the CFD results slightly over the experimental results, with the exception of TSR $=3.5$, where the experimental measurement results are higher than the numerical simulation. The average deviation between the CFD and experimental results is about $4.5 \%$.

Figure 10a-c displays the streamline distribution on the blade pressure side for a wider TSR. The red dotted line indicates the separation on the blade PS. For low TSR $(=1)$, the flow separates at the LE near the hub surface. However, as velocity increases, the separation line moves towards the LE to TE due to the increased angle of attack (AOA). At higher TSR (=4), the flow has separated more than $90 \%$ of the blade surface which most likely implies a post-stall condition. 


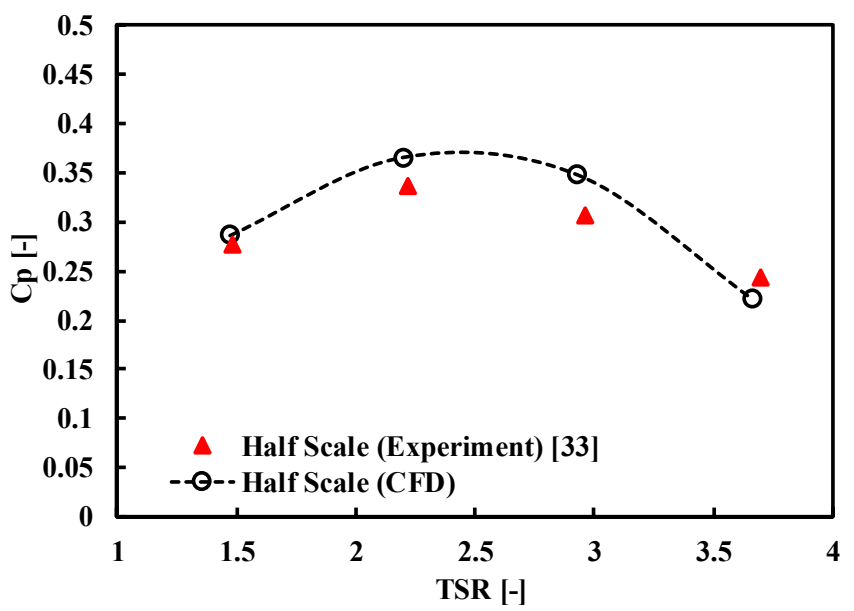

Figure 9. Comparison between experimental and numerical results (optimum inlet velocity is adopted at $2.5 \mathrm{~m} / \mathrm{s}$ for computational study).

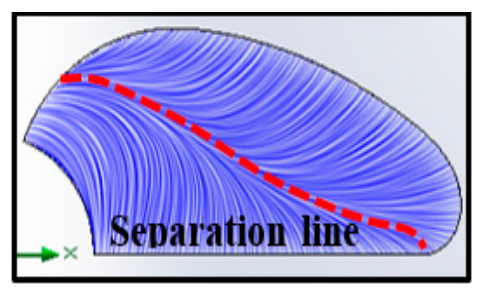

(a)

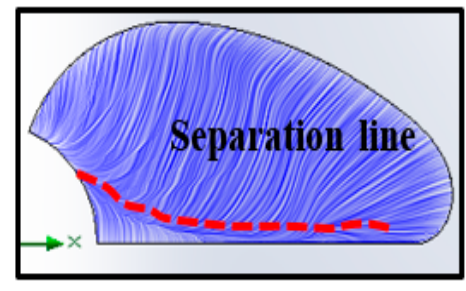

(b)

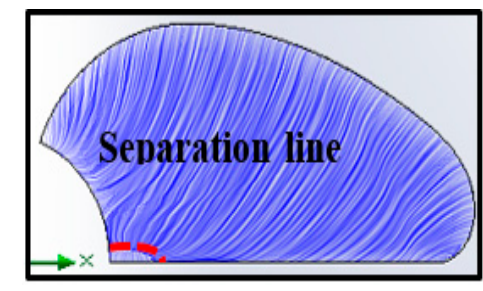

(c)

Figure 10. Streamline distribution on the blade pressure side at various TSR: $(\mathbf{a}) \operatorname{TSR}=1.0 ;(\mathbf{b}) \operatorname{TSR}=$ $2.0 ;$ (c) $T S R=4.0$.

Figures 11 and 12 illustrate the variation of the pressure contour at different TSR on the blade pressure side and suction side. At low TSR $(=1.0)$, the higher-pressure region is observed near the blade leading edge on the blade pressure side (Figure 11a). The results indicated that the higher-pressure region increases with increasing in TSR and shifts towards the leading edge to trailing edge on the blade pressure side. At higher TSR $(=4)$, the low-pressure region is noticed near the hub surface at leading-edge which implies the recirculation (Figure 11c). On the other side, the low-pressure region is observed on the blade suction side near the leading edge and along with the increase in TSR, the low-pressure region is also increasing (Figure 12).

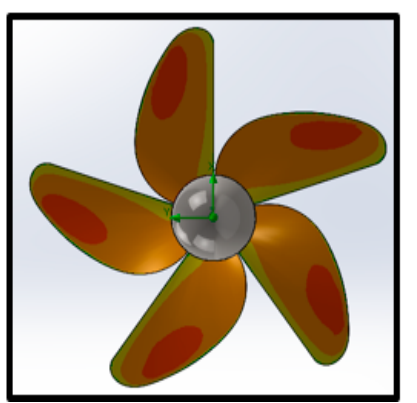

(a)

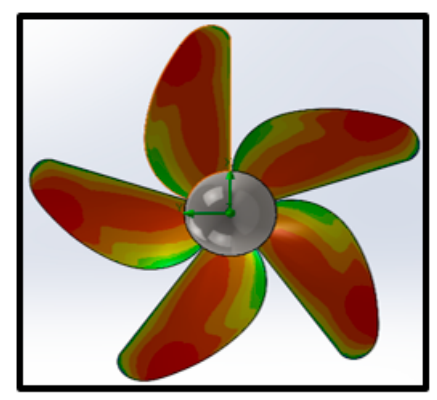

(b)

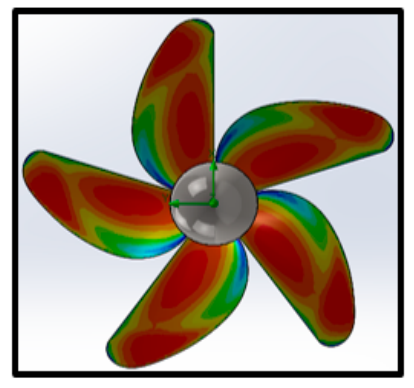

(c)

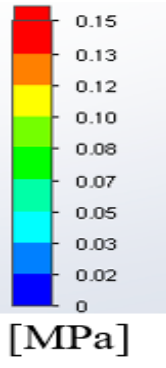

$[\mathrm{MPa}]$

Figure 11. Contour of pressure on the blade pressure side for various TSR: (a) TSR = 1.0; (b) TSR = 2.5;

(c) $T S R=4.0$.

Figure 13 illustrates the pressure contours at the mid-span of the flow passage at various TSR. It can be seen that the higher-pressure region moves from LE towards the TE of the blade at higher TSR. At TSR $=1.0$, the higher-pressure region covers almost $95 \%$ of the blade pressure side while the low-pressure 
region is found only at the blade leading edge of the blade suction side (SS). The higher-pressure region moves from the LE towards the TE of the blade at higher TSR. At TSR =2.5, a maximum-pressure region covers more than $40 \%$ of the pressure side with mostly located around the middle (Figure 13b). This may imply maximum performance conditions. Further increase in TSR makes the maximum pressure region moves towards the TE of the blade and the low-pressure region developed near the leading edge of the blade's pressure side because the stagnation point moves towards the blade suction side.

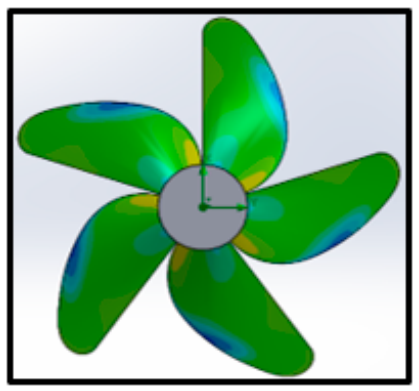

(a)

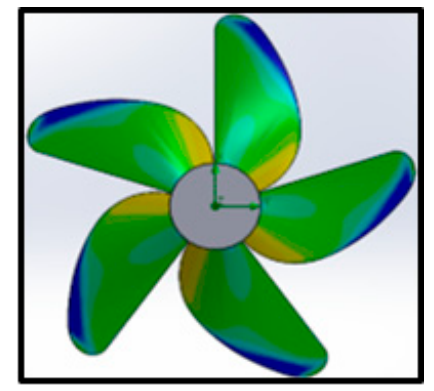

(b)

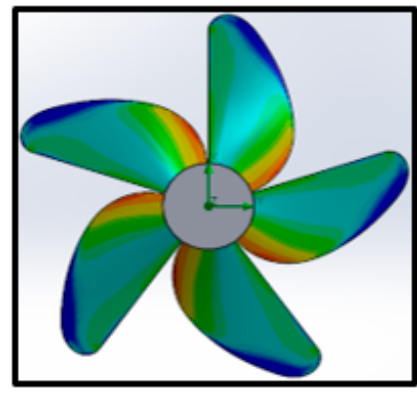

(c)

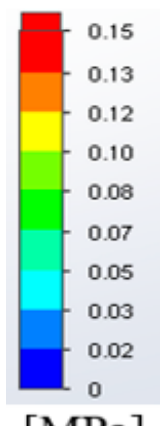

[MPa]

Figure 12. Contour of pressure on the blade suction side for different TSR: (a) TSR = 1.0; (b) TSR = 2.5; (c) $T S R=4.0$.

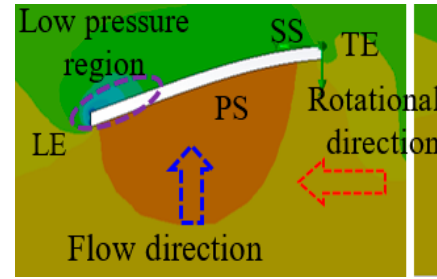

(a)

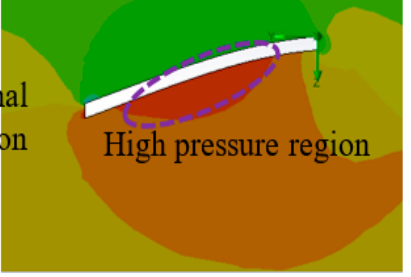

(b)

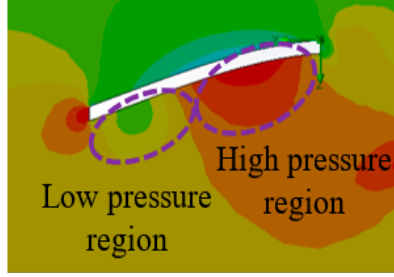

(c)

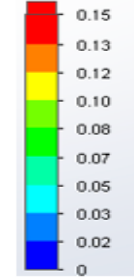

$\lceil\mathrm{MPa}\rceil$

Figure 13. Pressure distribution mid span of the flow passage for various TSR: (a) TSR = 1.0; (b) $T S R=2.5 ;$ (c) $T S R=4.0$.

The turbine is designed to operate in a wide range of TSR due to various angles of attack of the blade leading edge (LE). As the flow travels along the blade's leading edge, it may separate if the inlet velocity or angle of attack is high. Figure 14 a shows that the angle difference between axial flow $\left(V_{a}\right)$ and relative flow $\left(V_{r}\right)$ is small. This indicates that the flow is attached to the blade's pressure side (PS). With an increase in inlet velocity, the angle between inlet flow and relative flow should also increase, which indicates that the stagnation point should move towards the blade suction side (SS) (as described in Figure 13) and flow separates. At TSR $=4$, it is observed that the recirculation region found on the leading edge of the blade's PS.

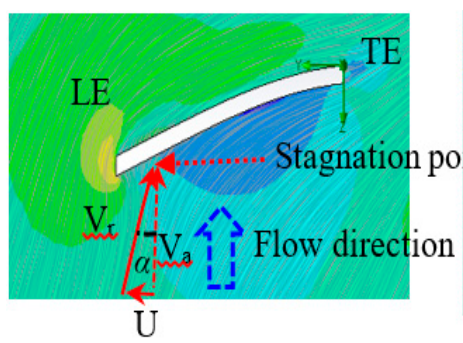

(a)

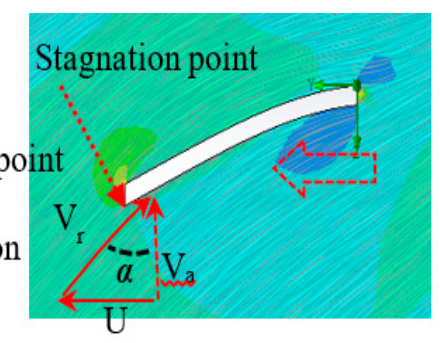

(b)

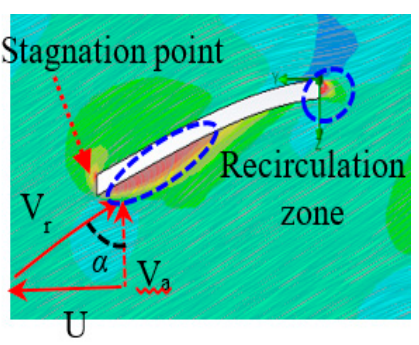

(c)

Figure 14. Velocity distribution mid span of the flow passage for various TSR: (a) $T S R=1.0$; (b) $T S R=2.5$; (c) $T S R=4.0$. 


\section{Generator and Turbine Running Characteristics}

Figures 15 and 16 show the distribution of output power and drag force at various RPM, for a range of TSR from 0.5 to 4 . It can be observed that for a given velocity, the blade torque at zero is directly proportional to the rotational speed. On the other side, with an increase in rpm, the drag force increases for given inlet velocity as inferred in Figure 16.

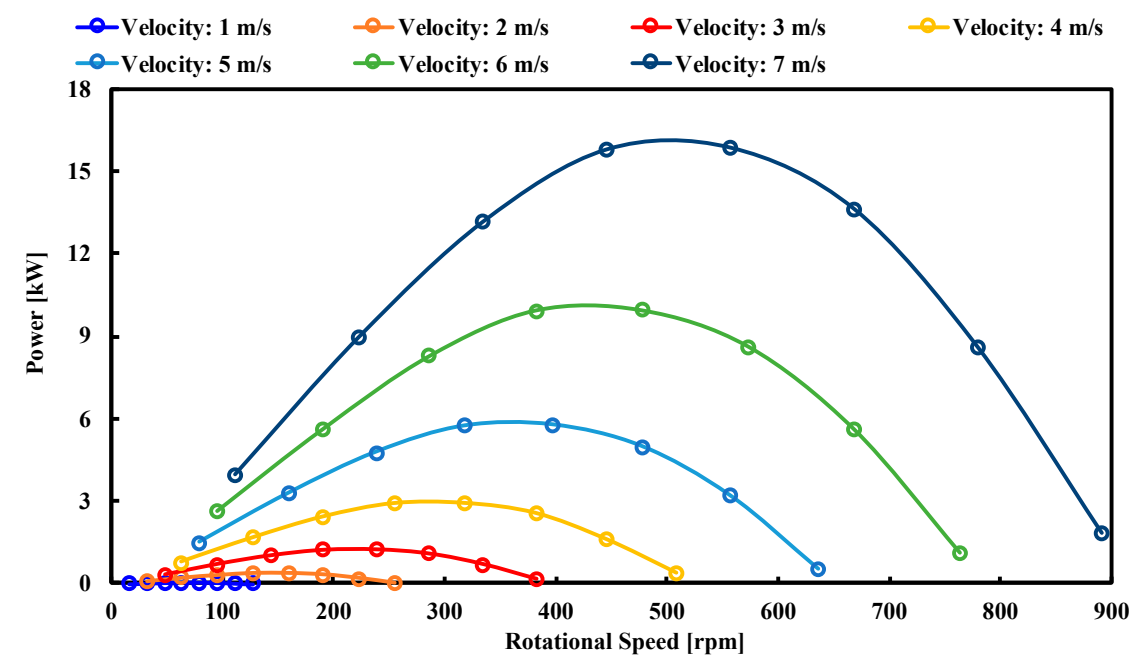

Figure 15. Power at different rotational speed.

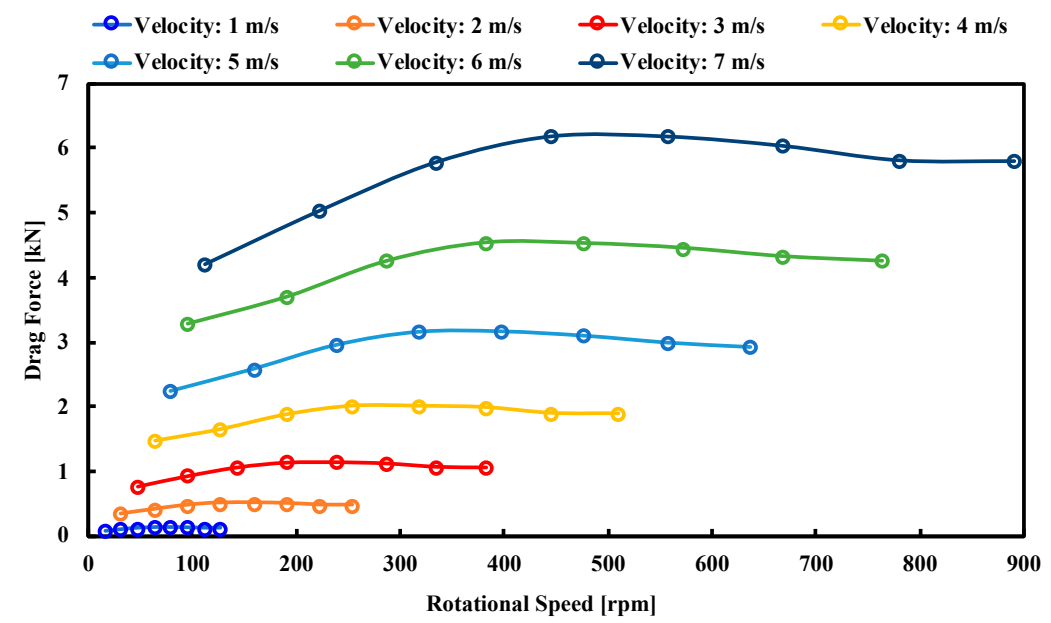

Figure 16. Drag force at different rotational speed.

Measured mechanical load input and electrical load output distribution against different RPM, for impedance range of 4.7-34.9 $\Omega$, are shown in Figures 17 and 18. For a given voltage, the low and high impedance implies low and high resistance, respectively. It is noticed that the mechanical and electrical power output decrease with an increase in impedance for a given voltage. On the other side, the electrical power out is slightly low as compared to the mechanical power input due to transmission loss. Subsequently, two different impedances of $4.7 \Omega$ and $34.9 \Omega$ are adopted for further studies. By incorporating these two impedances in Figure 15, the unique correlation between generator and turbine performance can be retrieved. The results are plotted in a dimensional form in Figure 19. It is important to be noted that the obtained correlation here is only as a function of impedance and independent of power output, drag force, rotational velocity, and blade torque. 


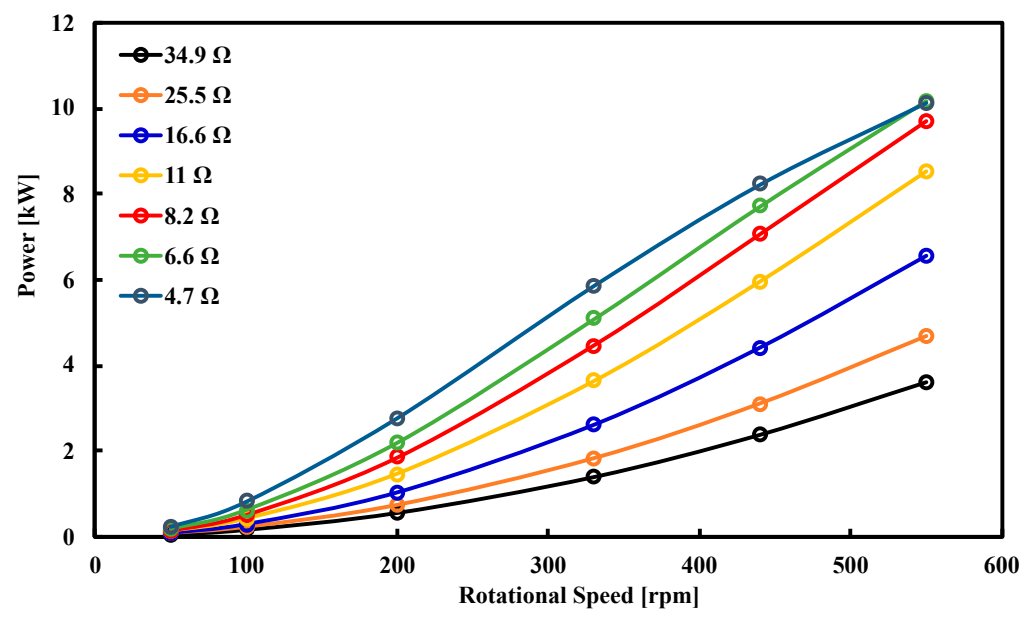

Figure 17. Measured Mechanical load input power and rotational speed of the full-scale generator in various load resistance: $R_{3 p h}=4.7-34.9 \Omega$.

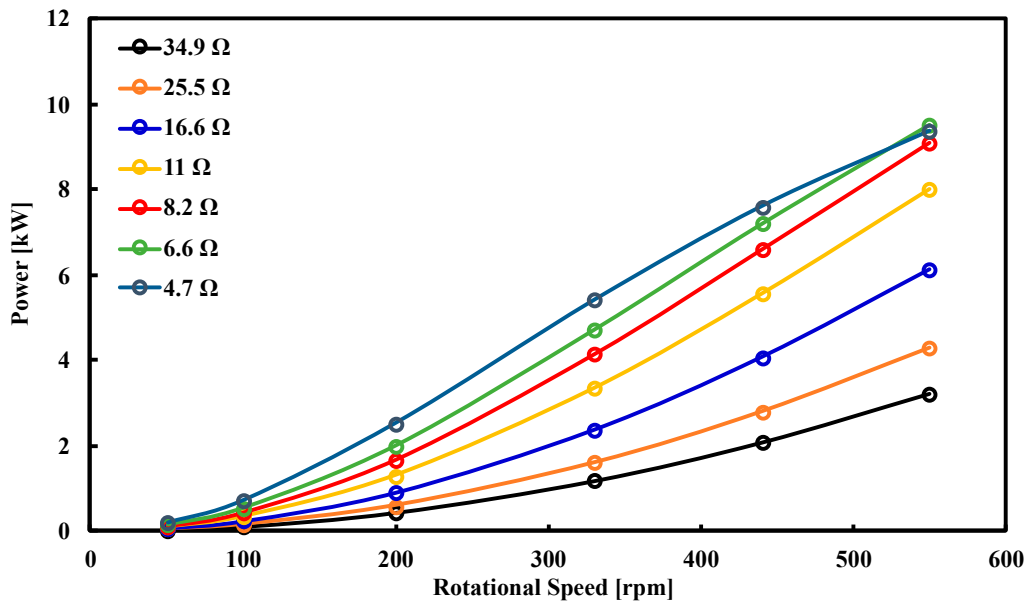

Figure 18. Measured Electrical load output power and rotational speed of the full-scale generator in various load resistance: $R_{3 p h}=4.7-34.9 \Omega$.

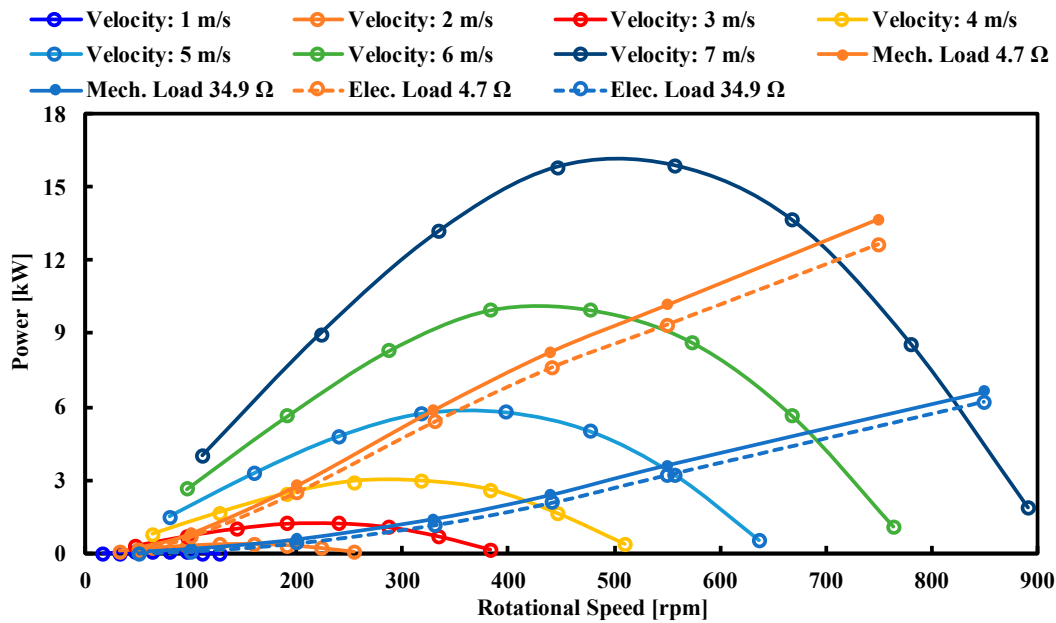

Figure 19. Power at different rotational speed.

Figure 20a,b show the power output for mechanical and electrical load against the inlet velocity for the mechanical load and electrical load, respectively. It can be observed that both mechanical and electrical loads results show a higher power achieved with lower impedance $(4.7 \Omega)$ compared to 
the higher impedance $(34.9 \Omega$ ) at velocity $>4.0 \mathrm{~m} / \mathrm{s}$. Below $4.0 \mathrm{~m} / \mathrm{s}$, on the other hand, both yield similar results in power. Furthermore, the rotational speed is much higher for higher impedance as shown in Figure 21. The drag force, however, is almost the same for both impedances for a given inlet flow as demonstrated in Figure 22. On the other hand, the torque is much higher for lower impedance than higher impedance as shown in Figure 23. This may be caused by the low resistance of the lower impedance.

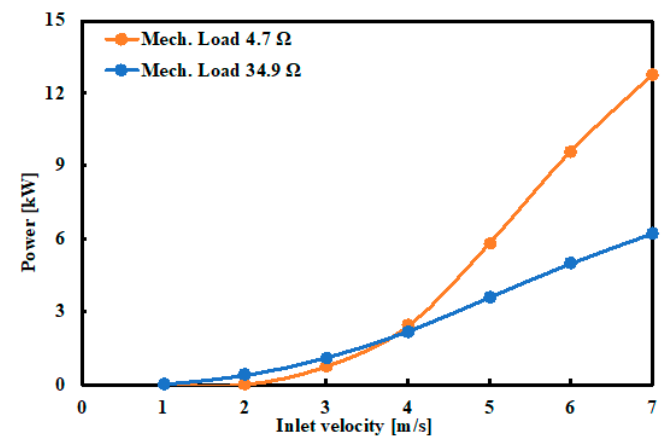

(a)

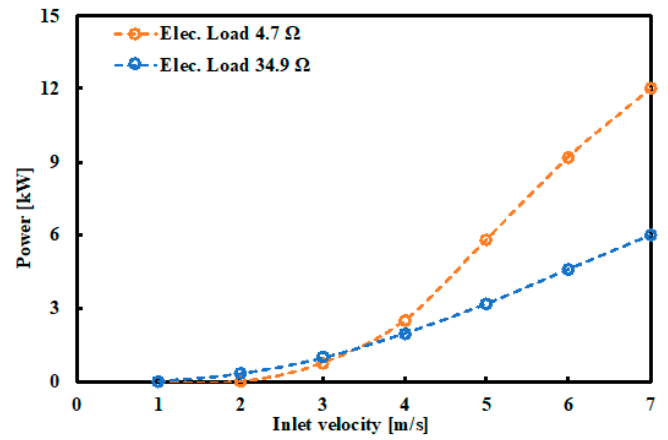

(b)

Figure 20. Power at different inlet velocity: (a) Mechanical Load; (b) Electrical Load.

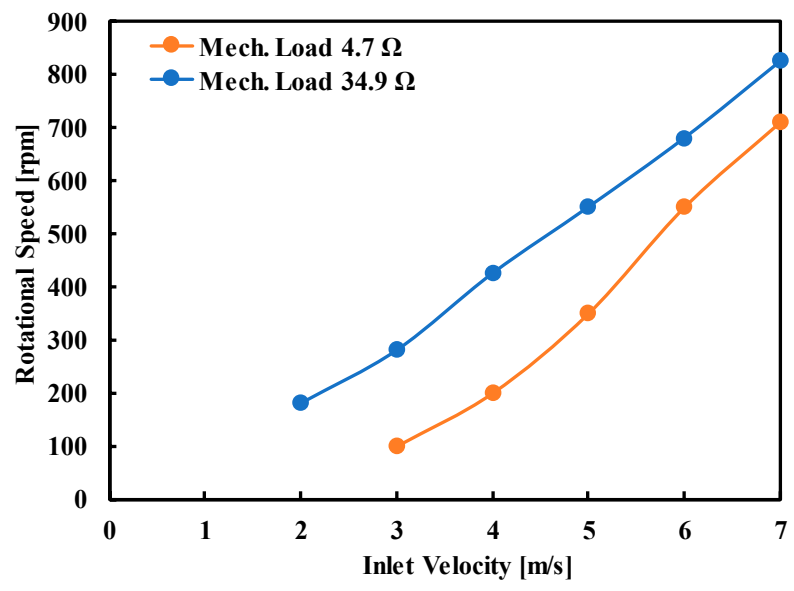

Figure 21. Rotational speed and inlet velocity co-relation.

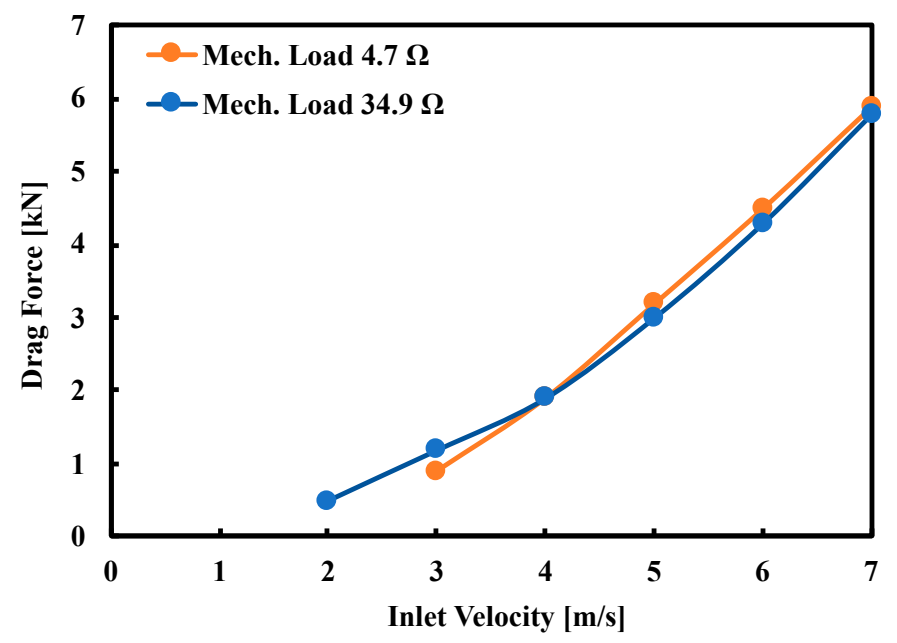

Figure 22. Drag force Vs Inlet velocity. 


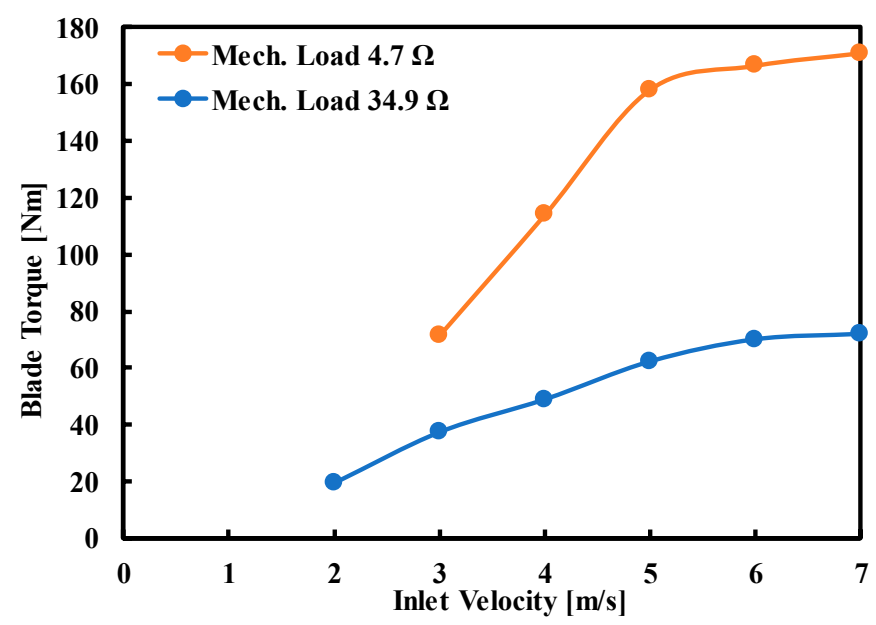

Figure 23. Blade torque vs. Inlet velocity.

Tables $3-5$ show output parameters for a mechanical load of $4.7 \Omega, 34.9 \Omega$, and electrical impedance of both, respectively. From this table, the turbine output and electrical output for a given input condition can be obtained. For example, the electrical load output is $34.9 \Omega$, and the power output is $3200 \mathrm{~W}$ or $3.2 \mathrm{~kW}$ for a corresponding generator rotational speed of $550 \mathrm{rpm}$. Therefore, for a given rpm and electrical load output, we can evaluate the turbine power, drag force, incoming water velocity and blade torque for the corresponding machinal load.

Table 3. Mechanical Load output of $4.7 \Omega$.

\begin{tabular}{cccccc}
\hline Vel. $(\mathbf{m} / \mathbf{s})$ & RPM & Power $\mathbf{( W )}$ & $\mathbf{\Omega}(\mathbf{r a d} / \mathbf{s})$ & $\mathbf{T} \mathbf{( N m )}$ & Drag Force $\mathbf{N})$ \\
\hline 1 & 0 & 0 & 0 & 0 & 0 \\
2 & 0 & 0 & 0 & 0 & 0 \\
3 & 100 & 750 & 10.47 & 71.62 & 900 \\
4 & 200 & 2390 & 20.94 & 114.11 & 1900 \\
5 & 350 & 5800 & 36.65 & 158.25 & 3190 \\
6 & 550 & 9600 & 57.60 & 166.68 & 4500 \\
7 & 710 & 12,725 & 74.35 & 171.15 & 5900 \\
\hline
\end{tabular}

Table 4. Mechanical load output of $34.9 \Omega$.

\begin{tabular}{cccccc}
\hline Vel. $(\mathbf{m} / \mathbf{s})$ & RPM & Power $(\mathbf{W})$ & $\boldsymbol{\Omega}(\mathbf{r a d} / \mathbf{s})$ & $\mathbf{T}(\mathbf{N m})$ & Drag Force $(\mathbf{N})$ \\
\hline 1 & 0 & 0 & 0 & 0 & 0 \\
2 & 180 & 370 & 18.85 & 19.63 & 500 \\
3 & 280 & 1100 & 29.32 & 37.52 & 1190 \\
4 & 425 & 2180 & 44.51 & 48.98 & 1900 \\
5 & 550 & 3590 & 57.60 & 62.33 & 3000 \\
6 & 680 & 4990 & 71.21 & 70.07 & 4300 \\
7 & 825 & 6220 & 86.39 & 72.00 & 5800 \\
\hline
\end{tabular}

Table 5. Electrical load output at different impedance.

\begin{tabular}{ccccc}
\hline Inlet Velocity & \multicolumn{2}{c}{ Load $\mathbf{3 4 . 9} \boldsymbol{\Omega}$} & \multicolumn{2}{c}{ Load $\mathbf{4 . 7} \boldsymbol{\Omega}$} \\
\hline Vel. (m/s) & RPM & Power $(\mathbf{W})$ & RPM & Power $(\mathbf{W})$ \\
\hline 1 & 0 & 41 & 0 & 0 \\
2 & 180 & 350 & 0 & 0 \\
3 & 280 & 990 & 100 & 760 \\
4 & 425 & 1990 & 200 & 2500 \\
5 & 550 & 3200 & 350 & 5820 \\
6 & 680 & 4610 & 550 & 9200 \\
7 & 825 & 6000 & 710 & 12,000 \\
\hline
\end{tabular}




\section{Conclusions}

The performance of a wave energy conversion device has been investigated by an experimental model and numerical simulation. The numerical analysis has been investigated by solving the steady, incompressible RANS equations with a modified $k-\varepsilon$ with a two-scale wall function turbulence closure model. The results have been compared with those of wave energy devices. The main conclusion obtained are outlined as follows:

- It is observed that the maximum Cp is 0.38 at TSR 2.5.

- The separation line moves from leading edge to trailing edge when increase in the TSR is noticed.

- It can be seen that impedance is a critical factor in determining the turbine starting characteristics.

- It is noticed that drag force increases with increase in inlet velocity.

- The running characteristics of the turbine are controlled by wave frequency and incoming velocity.

- Turbine output performance characteristics have been presented in Tables 3-5 so that for a given impedance and RPM, the power output can be estimated.

- It is recommended to investigate the effect of blade shape along with twist angle and chord length on the performance would be a future study.

Author Contributions: Conceptualization, T.S.; methodology, P.H.; software, P.H.; validation, P.H.; formal analysis, P.H.; investigation, P.H.; resources, H.T., J.F. and S.M.; data curation, P.H.; writing-original draft preparation, P.H.; writing-review and editing, K.P., H.T. and T.S; supervision, T.S.; All authors have read and agreed to the published version of the manuscript.

Funding: This work was supported by funding from the Okinawa Institute of Science and Technology Graduate University (OIST), the OIST R\&D Cluster Research Program, the OIST Proof of Concept (POC) Program, and Kokyo Tatemono Co. Ltd Research Trust fund for Ocean Energy Project.

Acknowledgments: The authors would like to thank members of the Quantum Wave Microscopy Unit at OIST for their support in this work.

Conflicts of Interest: The authors declare no conflict of interest.

\section{Nomenclature}

$\begin{array}{ll}\text { Abbreviation } & \text { Definition } \\ \text { AOA } & \text { Angle of attack } \\ \text { CAD } & \text { Computer-aided design } \\ \text { CFD } & \text { Computational fluid dynamics } \\ \text { FVM } & \text { Finite volume method } \\ \text { LE } & \text { Leading edge } \\ \text { OIST } & \text { Okinawa Institute of Science and Technology Graduate University } \\ \text { PS } & \text { Pressure side } \\ \text { RB } & \text { Rotor blade } \\ \text { RPM } & \text { Revolution per minute } \\ \text { RANS } & \text { Reynolds-averaged Navier-Stokes equations } \\ \text { SIMPLE } & \text { Semi-implicit method for pressure linked equations } \\ \text { SWFS } & \text { Solidworks flow simulation } \\ \text { SS } & \text { Suction side } \\ \text { SETE } & \text { Static extended trailing edge } \\ \text { TE } & \text { Trailing edge } \\ \text { TSR } & \text { Tip speed ratio } \\ \text { WEC } & \text { Wave energy converter }\end{array}$




$\begin{array}{ll}\text { Symbols } & \\ b & \text { Blade span }(\mathrm{m}) \\ C & \text { Chord length }(\mathrm{m}) \\ C_{l} & \text { Lift coefficient }(-) \\ C_{p} & \text { Coefficient of the power }(-) \\ \mathrm{D}_{\mathrm{t}} & \text { Tip diameter }(\mathrm{m}) \\ \mathrm{D}_{\mathrm{h}} & \text { Hub diameter }(\mathrm{m}) \\ \lambda & \text { Tip speed ratio }(-) \\ p & \text { Pressure }\left(\mathrm{N} / \mathrm{m}^{2}\right) \\ R_{t} & \text { Tip radius }(\mathrm{m}) \\ r & \text { Radius }(\mathrm{m}) \\ \mathrm{S} & \text { Blade swept area }\left(\mathrm{m}^{2}\right) \\ T & \text { Torque generated by RB (Nm) } \\ t & \text { Blade thickness }(\mathrm{m}) \\ V_{a} & \text { Axial velocity }(\mathrm{m} / \mathrm{s}) \\ V_{r} & \text { Relative inlet velocity }(\mathrm{m} / \mathrm{s}) \\ U_{R} & \text { Mean blade speed }(\mathrm{m} / \mathrm{s}) \\ U & \text { Blade tip velocity }(\mathrm{m} / \mathrm{s}) \\ z & \text { Number of RB }(-) \\ \eta & \text { Efficiency }(-) \\ \rho_{a} & \text { Density of air }\left(\mathrm{g} / \mathrm{m}^{3}\right) \\ \phi & \text { Flow coefficient }(-) \\ \theta & \text { Blade twist angle }\left({ }^{\circ}\right) \\ \alpha & \text { Angle of attack }\left(^{\circ}\right) \\ \omega & \text { Angular velocity }(\mathrm{rad} / \mathrm{s}) \\ & \end{array}$

\section{References}

1. REN21. Renewables Global Status Report; Tech. Rep.; REN21 Secretariat: Paris. France, 2018.

2. Falcão, A.F.O.; Joao, C.C.H. Oscillating-water-column wave energy converters and air turbines: A review. Renew. Energy 2016, 85, 1391-1424. [CrossRef]

3. Raghunathan, S.; Tan, C.P. Efficiency Starting Torque and Prevention of Run-Away with Wells Self-Rectifying Turbines. In Proceedings of the 2nd International Symposium on Wave and Tidal Energy, Cambridge, UK, 1981; pp. 207-217.

4. Raghunathan, S. A methodology for Wells turbine design for wave energy conversion. Proc. Inst. Mech. Eng. Part A J. Power Energy 1995, 209, 221-232. [CrossRef]

5. Pawitan, K.A.; Dimakopoulos, A.S.; Vicinanza, D.; Allsop, W.; Bruce, T. A loading model for an OWC caisson based upon large-scale measurements. Coast. Eng. 2019, 145, 1-20. [CrossRef]

6. Brito-Melo, A.; Gato, L.M.C.; Sarmento, A.J.N.A. Analysis of Wells Turbine Design Parameters by Numerical Simulation of the OWC Performance. Ocean. Eng. 2002, 29, 1463-1477. [CrossRef]

7. Mohamed, M.H.; Janiga, G.; Pap, E.; Thévenin, D. Multi-Objective Optimization of the Airfoil Shape of Wells Turbine Used for Wave Energy Conversion. Energy 2011, 36, 438-446. [CrossRef]

8. Webster, M.; Gato, L.M.C. The Effect of Rotor Blade Sweep on the Performance of the Wells Turbine. Int. J. Offshore Polar Eng. 2010, 9, 233-240.

9. Kim, T.H.; Setoguchi, T.; Takao, M.; Kaneko, K.; Santhakumar, S. Study of Turbine with Self-Pitch-Controlled Blades for Wave Energy Conversion. Int. J. Therm. Sci. 2002, 41, 101-107. [CrossRef]

10. Mohamed, M.H.; Shaaban, S. Optimization of Blade Pitch Angle of an Axial Turbine Used for Wave Energy Conversion. Energy 2013, 56, 229-239. [CrossRef]

11. Mohamed, M.H.; Sameh, S. Numerical optimization of axial turbine with self-pitch-controlled blades used for wave energy conversion. Int. J. Energy Res. 2014, 38, 592-601. [CrossRef]

12. Takao, M.; Setoguchi, T.; Kinoue, Y.; Kaneko, K. Wells Turbine with End Plates for Wave Energy Conversion. Ocean. Eng. 2007, 34, 1790-1795. [CrossRef]

13. Raghunathan, S.; Tan, C.P. Effect of Blade Profile on the Performance of the Wells Self-Rectifing Air Turbine. Int. J. Heat Fluid Flow 1985, 6, 369-379. 
14. Gato, L.M.C.; Webster, M. An Experimental Investigation into the Effect of Rotor Blade Sweep on the Performance of the Variable-Pitch Wells Turbine. Proc. Inst. Mech. Eng. Part. A J. Power Energy 2001, 215, 611-622. [CrossRef]

15. Suzuki, M.; Arakawa, C. Influence of Blade Profiles on Flow around Wells Turbine. Int. J. Fluid Mach. Syst. 2008, 1, 148-154. [CrossRef]

16. Takao, M.; Setoguchi, T.; Kinoue, Y.; Kaneko, K. Effect of end plates on the performence of a Wells turbine for wave energy conversion. J. Therm. Sci. 2006, 15, 319-323. [CrossRef]

17. Kim, T.H.; Takao, M.; Setoguchi, T.; Kaneko, K.; Inoue, M. Performance Comparison of Turbines for Wave Power Conversion. Int. J. Therm. Sci. 2001, 40, 681-689. [CrossRef]

18. Thakker, A.; Abdulhadi, R. Effect of blade profile on the performance of Wells turbine under unidirectional sinusoidal and real sea flow conditions. Int. J. Rotating Mach. 2007, 2007, 51598. [CrossRef]

19. Halder, P.; Samad, A.; Kim, J.H.; Choi, Y.S. High performance ocean energy harvesting turbine design-A new casing treatment scheme. Energy 2015, 86, 219-231. [CrossRef]

20. Halder, P.; Samad, A. Torque and efficiency maximization for a wave energy harvesting turbine: An approach to modify multiple design variables. Int. J. Energy Res. 2017, 41, 1014-1028. [CrossRef]

21. Halder, P.; Samad, A.; Thevenin, D. Improved design of a Wells turbine for higher operating range. Renew. Energy 2017, 106, 122-134. [CrossRef]

22. Halder, P.; Mohamed, M.H.; Samad, A. Wave energy conversion: Design and shape optimization. Ocean. Eng. 2018, 150, 337-351. [CrossRef]

23. Kumar, P.M.; Samad, A. Nature-inspired design of a turbine blade harnessing wave energy. Proceedings of the Institution of Mechanical Engineers. Part. A J. Power Energy 2019. [CrossRef]

24. Kumar, P.M.; Halder, P.; Husain, A.; Samad, A. Performance enhancement of Wells turbine: Combined radiused edge blade tip, static extended trailing edge, and variable thickness modifications. Ocean. Eng. 2019, 85, 47-58. [CrossRef]

25. Gomes, R.P.F.; Henriques, J.C.C.; Gato, L.M.C.; Falcão, A.F.O. Multi-point aerodynamic optimization of the rotor blade sections of an axial-flow impulse air turbine for wave energy conversion. Energy 2012, 45, 570-580. [CrossRef]

26. Badhurshah, R.; Samad, A. Multiple surrogate-based optimization of a bidirectional impulse turbine for wave energy conversion. Renew. Energy 2015, 74, 749-760. [CrossRef]

27. Ezhilsabareesh, K.; Rhee, S.H.; Samad, A. Shape optimization of a bidirectional impulse turbine via surrogate models. Eng. Appl. Comput. Fluid Mech. 2018, 12, 1-12. [CrossRef]

28. Badhurshah, R.; Dudhgaonkar, P.; Jalihal, P.; Samad, A. High efficiency design of an impulse turbine used in oscillating water column to harvest wave energy. Renew. Energy 2018, 121, 344-354. [CrossRef]

29. Shintake, T. Harnessing the Power of Breaking Waves. In Proceedings of the AWTEC 2016, 3rd Asian Wave and Tidal Energy Conference, Singapore, 24-28 October 2016.

30. Shintake, T.; Shirasawa, K.; Fujita, J.; Misumi, S.; Halder, P.; Nagahama, T.; Shindou, T.; Taggart, H.; Hikaru, K.; Takebe, H. Results of Wave Energy Experiments in the Maldives. In Proceedings of the European Wave and Tidal Energy Conference (EWTEC-2019), Napoli, Italy, 1-6 September 2019.

31. Takebe, H.; Shirasawa, K.; Fujita, J.; Misumi, S.; Halder, P.; Shintake, T. Wave Power Measurement at Braking Wave Zone in Maldives using Horizontal-Axis Turbine WEC. In Proceedings of the European Wave and Tidal Energy Conference (EWTEC-2019), Napoli, Italy, 1-6 September 2019.

32. Takebe, H.; Minami, J.; Fujita, J.; Shirasawa, K.; Toda, K.; Shintake, T. Water Speed Measurements at a Wave Energy Converter Test Site. In Proceedings of the EWTEC 2017, Cork, Ireland, 28 August-1 September 2017.

33. Takebe, H.; Shirasawa, K.; Fujita, J.; Misumi, S.; Shintake, T. Development of OIST Wave Energy Converter Monitoring System for Maldives Island Experiment. J. Energy Power Eng. 2018, 12, 375-384.

34. Enhanced Turbulence Modeling in Solidworks Flow Simulation; Technical Paper; Dassault Systemes, SolidWorks Corporation: Waltham, MA, USA, 2013; pp. 1-21.

(C) 2020 by the authors. Licensee MDPI, Basel, Switzerland. This article is an open access article distributed under the terms and conditions of the Creative Commons Attribution (CC BY) license (http://creativecommons.org/licenses/by/4.0/). 